İşletme Akademisi Dergisi
2020, 1 (4): $364-384$
DOI:10.26677/TR1010.2020.630
Dergi web sayfasi: www.isakder.org

Derleme Makalesi

\title{
Avrupa Borç Krizinin Ortaya Çıkışı ve Gelişimi*
}

\section{Dr. Mehmet KUZU}

Bayburt Üniversitesi, İktisadi ve İdari Bilimler Fakültesi, İşletme Bölümü, Muhasebe-Finansman Anabilim Dalı, Bayburt.

mehmetkuzu86@gmail.com www.orcid.org/0000-0001-5354-4368

\section{Özet}

Bir parasal birlik alanı olarak Euro Bölgesi 1999 yılında kurulmuştur. Euro Bölgesinin kurulmasından sonra $\mathrm{AB}$ ve Euro Bölgesinde borçlanma maliyetleri azalmaya başlamıştır. Borçlanma maliyetlerindeki azalış, Euro Bölgesinde borçlanmaya dayalı ekonomik büyümeyi daha avantajlı hale getirmiştir. Bu durum ise Euro Bölgesi ülkelerinin kamu borçlarının artmasına neden olmuştur. Euro Bölgesinde parasal birliği destekleyen mali birliğin oluşturulmaması, Euro Bölgesindeki bazı ülkelerin mali disiplinlerinin zayıf olması ile makroekonomik yönden kırılganlıklara sahip olmaları; diğer ülkelere kıyasla bu ülkelerde kamu borçlarının GSYİH’ ya oranının daha yüksek seviyelere çıkmasına sebep olmuştur. 2008 Küresel krizi ile bu ülkelerin finansal kırılganlıkları artmıştır. Artan finansal kırılganlık başta Yunanistan olmak üzere Euro Bölgesi Güney ülkelerinde borç krizlerine neden olmuştur. Bu çalışmanın amacl; Avrupa borç krizinin ortaya çıkış sürecini inceleyerek krizin gelişimini analiz etmektir. Sonuç olarak Euro Bölgesinde güney ülkelerinin enflasyonu baskılayamamaları sonucu değerlenen reel döviz kuru nedeniyle kamu borçları ile finanse edilen cari açık sorunlarının olduğu gözlemlenmiştir. Küresel kriz sonrası artan risk fiyatlamaları nedeniyle bu ülkelerin mevcut borçlanma dinamikleri bozulmuş ve Avrupa Borç Krizi ortaya çıkmıştır.

Anahtar Kelimeler: Avrupa Borç Krizi, Euro Bölgesi, Finansal Krizler

Makale Gönderme Tarihi: 30.07.2020

Makale Kabul Tarihi: 12.12 .2020

* Bu çalışma, Mehmet Kuzu tarafından 2014 yılında Gazi Üniversitesi Sosyal Bilimler Enstitüsü İşletme Anabilim dah/Muhasebe-Finansman Bilim dalında yazllan "Reel Efektif Döviz Kuru Endeksini Etkileyen Faktörlerin Avrupa Borç Krizi Çerçevesinde Analizi" isimli yayımlanmamış yüksek lisans tezinden türetilmiştir.

\section{Önerilen Atıf:}

Kuzu, M., (2020). Avrupa Borç Krizinin Ortaya Çıkışı ve Gelişimi, İşletme Akademisi Dergisi, 1(4): 364-384.

(C) 2020 İşletme Akademisi Dergisi. 


Journal of Business Academy
$2020,1(4): 364-384$
DOI:10.26677/TR1010.2020.630
Web pages: www.isakder.org

$\underline{\underline{R e v i e w ~ A r t i c l e ~}}$

\title{
Euro Zone Debt Crises
}

\section{Dr. Mehmet KUZU}

Bayburt University, Faculty of Economics and Administrative Sciences, Department of Business Management, Bayburt. mehmetkuzu86@gmail.com www.orcid.org/0000-0001-5354-4368

\begin{abstract}
The Euro Zone was established in 1999 as a monetary union area. After the establishment of the Euro Zone, borrowing costs started to decrease in the EU and Euro Zone. The decrease in borrowing costs made economic growth based on borrowing more advantageous in the Euro Area. This situation led to an increase in the public debts of the Euro Area countries. Failure to establish a financial union supporting the monetary union in the Eurozone, weak financial disciplines of some countries in the Euro Area, and their macroeconomic vulnerabilities; Compared to other countries, the ratio of public debts to GDP increased in these countries. With the 2008 global crisis, the financial vulnerabilities of these countries have increased. Increased financial vulnerability caused debt crises in the Euro Area Southern countries, especially in Greece. The purpose of this study; to examine the emergence process of the European debt crisis and to analyze development of crisis. As a result, it was observed that the current account deficit financed by public debt, due to the real exchange rate appreciated as a result of the inability of the southern countries to suppress inflation, in the Euro Zone. Due to the increasing risk pricing after the global crisis, the existing borrowing dynamics of these countries deteriorated and the European debt crisis emerged.
\end{abstract}

Keywords: European Debt Crisis, Euro Zone, Financial Crises.

Received: 30.07 .2020

Accepted: 12.12 .2020

\section{Suggested Citation:}

Kuzu, M., (2020). Euro Zone Debt Crises, Journal of Business Academy, 1(4): 364-384.

(c) 2020 Journal of Business Academy. 


\section{Giriş}

Avrupa Birliği'nin (AB) uzun vadede kurumsal amacı ekonomik ve siyasi birliğe dönüşmektir. $\mathrm{Bu}$ amaç, ekonomik ve siyasi anlamda uzun bir süreci gerektirmektedir. $\mathrm{AB}$ üyesi ülkeler arasında ekonomik ve mali birliğin sağlanabilmesi bu sürecin en önemli kilometre taşlarından biridir. Ekonomik ve mali birliğin sağlanmasının ilk adımı parasal birliğin sağlanmasıdır. Bir parasal birlik alanı olarak Euro Bölgesi veya bir diğer adı ile Avrupa Para Birliği 1999 yılında kurulmuştur.

Euro Bölgesinin kurulmasından sonra $\mathrm{AB}$ ve Euro Bölgesinde borçlanma maliyetleri Alman markının borçlanma maliyetlerine yakınsamıştır. Bu durum Euro Bölgesinde borçlanmaya dayalı ekonomik büyümeyi daha avantajlı hale getirmiştir ve Euro Bölgesi ülkelerinin kamu borçlarının artmasına neden olmuştur.

Euro Bölgesinde parasal birliği destekleyen mali birliğin oluşturulmaması, Euro Bölgesi güney ülkelerinin mali disiplinlerinin zayıf olması ile makroekonomik yönden kırılganlıklara sahip olmaları; diğer ülkelere kıyasla bu ülkelerde kamu borçlarının GSYİH' ye oranının daha yüksek seviyelere çıkmasına sebep olmuştur.

2008 Küresel krizi ile bu ülkelerin finansal kırılganlıkları artmıştır.2008 yılında ortaya çıkan Küresel Finansal Kriz, küresel sistem üzerinde risk fiyatlamalarını artırmıştır. Artan küresel risk fiyatlamaları Euro Bölgesinde borçlanma maliyetlerini yükseltmiştir. Küresel Finansal Krizin etkileri Euro Bölgesinde makroekonomik kırılganlıklara sahip ülkelerde daha fazla hissedilmiştir. Euro Bölgesinde mali disiplin ve makroekonomik göstergeler açısından en zayıf ülkelerden biri Yunanistan'dır. Bu bağlamda Küresel Finansal Krizle birlikte artan risk algısı sonrası, Yunanistan'ın borçlanma maliyetleri diğer Euro Bölgesi ülkelerine kıyasla daha fazla artmiştır.

Yunanistan'da 2009 yllı sonbaharında göreve gelen yeni hükümet Yunanistan'ın geçmişe dair makroekonomik verilerini güncelleyerek Yunanistan'ın kamu borçlarını ödeyemeyeceğini ilan etmiştir. Yunanistan kamu borçlarının ödenebilirlik derecesi ile ilgili yapılan bu güncelleme Euro Bölgesi piyasalarında panik havası ortaya çıkarmıştır.

Piyasalarda bir Euro Bölgesi ülkesinin iflası kaynaklı ortaya çıkan panik havası; yatırımcılar nezdinde Euro Bölgesi ve $A B^{\prime}$ nin geleceğine ilişkin soru işaretlerini ortaya çıkarmıştır. $\mathrm{Bu}$ çerçevede, Euro Bölgesinde Küresel Finansal Krizle ortaya çıkan yüksek derecede risk seviyesi daha fazla artarak borçlanma maliyetlerini daha fazla artma eğilimine sürüklemiştir.

Küresel Finansal Kriz ve Yunanistan'ın iflası sonrası Euro Bölgesinde makroekonomik kırılganlıklara sahip olan ülkelerin borçlanma maliyetleri diğer Euro Bölgesi ülkelerine nazaran çok daha fazla artmıştır. Artan borçlanma maliyetleri sonucu Euro Bölgesinde makroekonomik zayıflıklara sahip olan ülkeler, artan kamu borçlarının geri ödenmesinde başarılı olamamışlar ve borçlarının geri ödenmeme riskleri artmaya başlamıştır. Risk artışı ile borçlanma maliyetlerinin tekrar yükselmesi, kamu borçlarının tekrardan borçlanma yolu ile finanse edilmesini neredeyse imkânsız hale getirmiş ve Avrupa Borç Krizi ortaya çıkmıştır.

\section{Avrupa Borç Krizinin Gelişimi}

Günümüzde finansal küreselleşme ve finansal pazarların entegrasyonu ile sermaye hareketliliği artarak krizleri daha yaygın hale getirmiştir (Bordo ve Eichengreen, 1999, Rangau ve Burietz, 2013: 35). Bu krizler birçok benzer özelliklere sahip olmalarına rağmen kendine ait özellikleri vardır (Hautcoeur,2011, Rangau ve Burietz, 2013:35). 
Günümüzde en son yaşanan ekonomik krizlerden biri de Avrupa Borç Krizi' dir. Avrupa Borç Krizi' nin en önemli spesifik özelliklerinden biri krizin bir parasal birlik alanı içerisinde ortaya çıkmasıdır.

Bir parasal birlik alanı olarak Euro Bölgesi 2009 yılı sonlarına kadar başarılı bir birlik olarak kabul edilmiştir. Ancak; parasal birliğin tasarımının yanlış yapılandırılması ve parasal birlik alanı içerisinde yer alan güney ülkelerinin makroekonomik anlamda kırılganlıklara sahip olması parasal birlik alanı içerisinde ekonomik krizler ortaya çıkma riskini artırmıştır.

Avrupa Borç Krizi çerçevesinde ilk olarak ifade edilebilecek hususlardan biri krizi derinden yaşayan ülkelerde krizi derinleştiren faktörlerin farklılaşmasıdır. Bir başka ifade ile Euro Bölgesinde Portekiz, İrlanda, İtalya, Yunanistan ve İspanya'da (PIIGS) yaşanan kamu borç krizlerinin nedenleri her ülkede farklılaşmaktadır. Avrupa Borç Krizi' nin ortaya çıkışını hızlandıran iki büyük kriz söz konusudur. Bu krizler, Küresel Finansal Kriz ve Yunan Hükümeti Borç Krizleridir.

2007 yılında A.B.D.' de konut kredileri piyasasında başlayan finansal krizin, 2008 yılı Eylül ayında Lehman Brothers' in iflası ile Küresel Finansal Krize dönüşmesi; yatırımcıların küresel sistem üzerindeki sistemik risk algılamasını artırmıştır. Bu durumun Euro Bölgesi üzerinde en somut anlamda yansımalarından biri; 10 yıllık devlet tahvil faizleri çerçevesinde Euro Bölgesinde borçlanma maliyetlerini artış trendine sürüklemesi olmuştur (Bkz. Şekil 1).

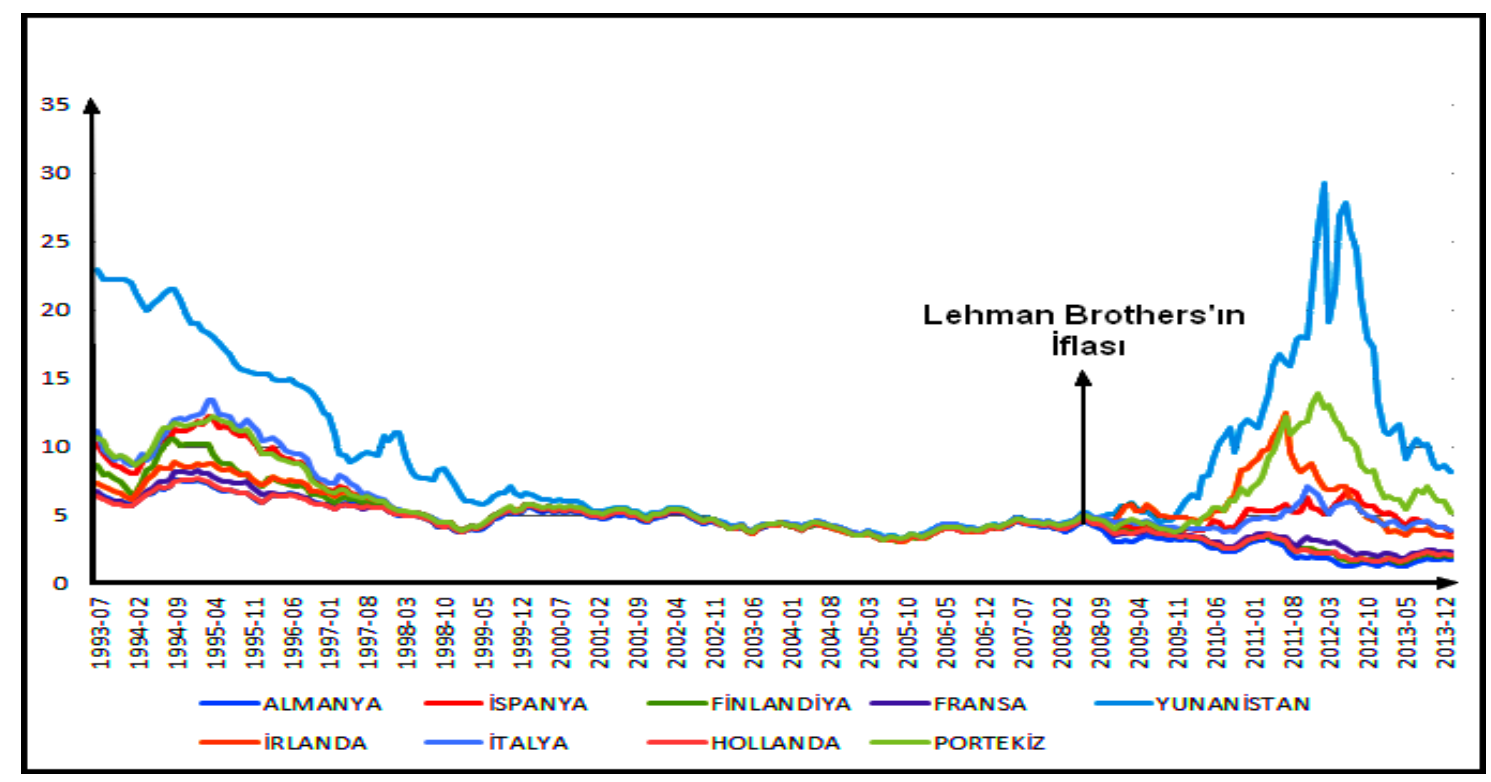

Şekil 1.: Euro Bölgesi Ülkelerinin 10 Yıllık Devlet Tahvil Faizleri

Kaynak:http://sdw.ecb.europa.eu/browseSelection.do?DATASET=0\&DATASET $=1 \&$ sfl1 $=4 \& F R E$ $\mathrm{Q}=\mathrm{M} \& \mathrm{sfl} 2=4 \&$ node $=$ SEARCHRESULTS\& $\mathrm{q}=$ long+term+interest+rate, (Erişim Tarihi, 17.01.2014).

Euro Bölgesinin kurulması ile Euro Bölgesinde Avrupa Borç Krizi' nin derinleştiği ülkelerin ihraç ettiği 10 yıllık devlet tahvil faizleri Almanya'nın 10 yıllık devlet tahvil faizlerine yaklaşmaya başlamıştır. Ancak 2008 yılında Küresel Finansal Krizin ortaya çıkması; Euro Bölgesinde 10 yıllık devlet tahvil faizlerini artış trendine sürüklemiştir. Bu artış trendin de Finansal kriz esnasında $\mathrm{AB}$ genelinde ortak politika çerçevesi oluşturulamamasının ve Küresel Finansal Kriz ile bağlantılı 
olarak özellikle İrlanda' da bankalarının İrlanda hükümeti tarafından kurtarılması risk artışının tetiklemesine neden olmuştur ${ }^{1}($ Ergin,2013:6).

Küresel Finansal Kriz sonrası Euro Bölgesinde borçlanma maliyetlerinin artış trendine girmesi; Euro Bölgesinin A.B.D. kaynaklı bir bankacılık ve finans krizine duyarlılık derecesinin neden bu kadar yüksek olduğu sorusunu ön plana çıkarmaktadır. Bu soruya cevap olarak üç husus sıralanabilir.

Bu hususlardan birincisi, Küresel Finansal Kriz sonrası tüm küresel sistemde ortaya çıkan finansal istikrarsızlığın reel sektörleri etkileyerek küresel sistemde durgunluğa ve daralmaya neden olmasidır

İkinci husus, Euro Bölgesi ve A.B.D. ekonomileri arasındaki sistemik bağlılık derecesinin yüksek olmasından ötürü A.B.D.' de ortaya çıkan bankacılık merkezli finansal krizin aktarım kanallarının etkili çalışmasıdır.

Üçüncü husus ise finansal krizler ve borç krizleri arasındaki sistemik ilişkidir. Tarihsel süreçte özellikle finansal merkezlerde ortaya çıan finansal kriz dalgalarını, borç krizleri izlemiştir (Hilsenrath, 2010, Kılıç ve Bayar, 2012:55).

Finansal krizler, dört ölümcül D (Ekomomik Gerileme, Gelirlerin azalması, Borç, Çöküş (economic downturns, revenues down, debt, downgrade)) ile ilişkilidir. Bunlar; ekonomik çöküş, gelirlerin azalışı, borçlar ve ekonomik küçülme olarak ifade edilebilir. Bankacılık temelli finansal krizleri, çarpıcı ekonomik çöküşler ve kamu gelirinde azalmalar takip eder. Gelirlerin azalması ile bütçe açıkları artar, artan bütçe açıkları finansman açığına neden olur. Finansman açığının kapatılması için borçlanmaya gidilir. Aşırı borçlanma sonrası kredi derecelendirme kuruluşlarının not indirimleri ortaya çıar (Reinhart, 2009: 2).

Kamu kesimi borç krizleri, genellikle likidite eksikliğinden (vadesi gelen yükümlülükleri ödeyecek kadar kısa vadeli veya likit varlık olmaması) bir başka ifade ile nakit akışı probleminden ya da ödeme gücünün yetersizliğinden kaynaklanmaktadır. Bir bakıma kamu borç krizleri; ülkenin kaynaklarının yükümlülüklerini karşılayamaması durumu olarak tanımlanabilir (Grafton, 2011:2, Kiliç ve Bayar,2012: 56).

Bankacılık krizi temelli finansal krizler ve kamu borç krizleri arasındaki ilişki bankacılık temelli bir finansal kriz olarak Küresel Finansal Krizin Euro Bölgesi üzerine izdüşümü literatürü destekler nitelikte gerçekleşmiştir. Euro Bölgesinde Küresel Finansal Krizi kamu borç krizleri takip etmiştir.

Küresel Finansal Krizin devamında Euro Bölgesinde kamu borç krizlerinin fitilini ateşleyen gelişmeler Yunanistan'dan gelmiştir. 2009 yılı Ekim ayında Papandreu Hükümetinin kendinden önce göreve gelen hükümetin bütçeye ilişkin verilerini revize etmiştir. Bu bağlamda kredi derecelendirme kuruluşlarının Yunanistan'ın kredi notunu indirmesi; yatırımcıların Yunanistan'ın yüksek düzeyde kamu borçlarını ödeyebilme gücü konusunda endişe yaşamasına neden olmuş ve Yunanistan'ın devlet tahvil faizleri ve CDS primleri yükselmeye başlamıştır.

Geniş anlamda borç krizi, borçlunun borçlarını çevirememesi anlamına gelirken, küresel finansal sistem zemininde borç krizi; borçlunun faiz ödemelerini yapamadığı ve dolaysıyla borçlarını çeviremez konumda olması anlamına gelmektedir (Akçay vd., 2013). Yunanistan'ın borçlanma maliyetlerinin artması da bu kapsamda incelenebilir.

'Çünkü İrlanda' da A.B.D.' de olduğu gibi konut kredilerinde balon etkisi görülmesinde ötürü Lehman Krizinin İrlanda' ya yansıması A.B.D' dekine benzer şekilde gerçekleşmiştir. 
$A B$ ve Euro Bölgesinin Merkez ülkeleri olarak ifade edilen Almanya ve Fransa'nın büyük finans kuruluşlarının bilançolarında Yunanistan ve diğer PIIGS ülkeleri tarafından ihraç edilen menkul kıymetler geniş bir yer tutmaktadır (Akçay vd, 2013). Bu nedenle, hali hazırda yüksek kaldıraç ve düşük sermaye yeterliliği oranları ile çalışan $A B^{\prime}$ nin bankacılık sektörünün toplam riski artmıştır. Bu kapsamda büyüme ve rekabet gücü krizi olarak başlayan kriz; Küresel Finansal Kriz ve parasal birliğin başarısız olması ile kamu borç krizine, borçlanma araçlarının da $A B$ bankalarının bilançolarında olmasından ötürü bir bankacılık krizine dönüşmüştür (Barosso, 2011).

Bu bağlamda, panik havası, Küresel Finansal Krizle gelen asimetrik dış şok ve Euro Bölgesinde varlık fiyatlarında meydana gelen ani değişmeler ile rekabet gücü ve büyüme krizi olarak başlayan kriz kamu borç krizi ve bankacılık krizlerine dönüşmüş ve Avrupa Borç Krizi ortaya çıkmıştır.

\section{Avrupa Borç Krizinin Ortaya Çıkış Nedenleri}

Avrupa Borç Krizinin nedenleri; Euro Bölgesi ülkeleri için seçilen büyüme modelinin tasarımından kaynaklanan nedenler, Euro Bölgesinde var olan yapısal sorunlar, krize geçiş sürecini hızlandıran katalizör faktörler olarak sınıflandırılabilir.

Euro Bölgesi bir optimal para alanı olarak tasarlanmamıştır. Euro Bölgesi tek para kullanmanın sağlayacağı faydalar çerçevesinde refah düzeyi düşük seviyedeki $\mathrm{AB}$ üyesi ülkeleri kalkındırmak amacıyla tasarlanan bir büyüme modelidir. Avrupa para birliği içerisinde PIIGS (Portekiz, İtalya, İrlanda, Yunanistan, İspanya) ülkelerinin makroekonomik kırılganlıklara sahip olmaları bu ülkelerde ekonomik krizlerin ortaya çıkma olasılığını artırmıştır. Parasal birlikle beraber ticaret, kredi ve finansal piyasaların aktarım mekanizmalarının daha etkin işlemesinden ötürü sorunlu ülkelerde ortaya çıkacak negatif görümün hızla tüm parasal birliğe yayılması riski ortaya çıkmaktadır.

Tek para uygulaması sonrası Euro bölgesinde döviz kuru riski ve işlem maliyetlerinin azalması sonucu finansal sistemin, bankacılık sektörü ile yüksek etkileşimi birlik üyesi ülkeler için borçlanmayı daha avantajlı hale getirmiştir. Ayrıca, AB içinde siyasi birliğe giden süreçte mali ve ekonomik birliğin sağlanmasında ortaya çıkan sorunların bir sonucu olarak güney ülkelerinde kuzeye nazaran enflasyonun yüksek olması; reel kurun değerlenmesine yol açmıştır. Bu durum rekabet gücü sorunu ve cari hesap açıklarına neden olmuştur.

Tablo 1: Avrupa Borç Krizinin Ortaya Çıkış Nedenleri

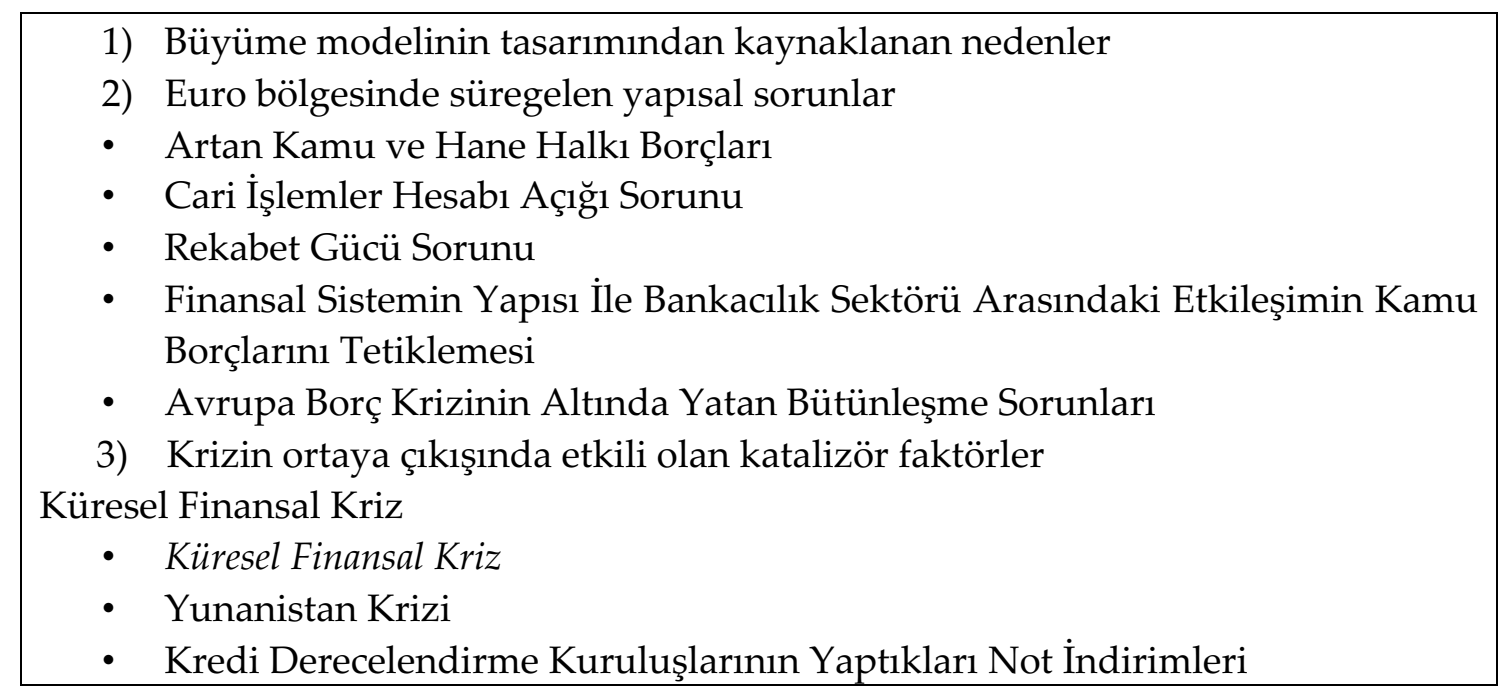


Cari hesap açıkları üzerinden oluşan dış finansman açıklarının borçlanma dinamiğine ilişkin riskler artmıştır. Küresel finansal krizin artırdığı sistemik risk ilk olarak makro finansal çerçevesi en zayıf parasal birlik üyesi ülke olan Yunanistan'ın riskini artırmıştır. Artan risk sonrası Yunanistan'ın borç dinamiği sürdürülemez hale gelmiştir. Yunanistan'ın krize sürüklenmesi nedeniyle diğer makro finansal açıdan zayıf ülkelerde kırılganlık düzeyine göre sırasıyla borç dinamiği bozulmuş ve PIIGS ülkelerinde borç krizleri ortaya çıkmıştır. Devamında $\mathrm{AB}$ yönetimi tarafından uygulamaya konan özellikle Yunanistan'a yönelik kurtarma paketleri ve kredi derecelendirme kuruluşlarının yaptıkları not indirimleri finansal piyasalarda panik havasına neden olarak krizin şiddetini derinleştirmiştir.

\section{Avrupa Borç Krizinin Yayılması}

\subsection{Avrupa Borç Krizinin Bulaşıcılığı ve Yayılma Kanalları}

Avrupa Borç Krizinin yayılması sürecinde ilk olarak bulaşıcılık kavramına değinilebilir. Bu doğrultuda günümüz küresel finansal sitemde daha çok finansal bulaşıcılık öne çıkmaktadır. Literatürde finansal bulaşıcılığa dair birçok farklı tanım yapılmıştır. Bununla birlikte genel olarak bulaşıcılık; "piyasalar arası aktarım mekanizmalarının kriz dönemlerinde farklılaşması" olarak tanımlanmaktadır (Corsetti vd., 2011, Küçüksaraç vd., 2012:2). Bu doğrultuda krizlerin bulaşıcılığında aktarım kanallarının ön plana çıktığı görülmektedir.

Krizlerin aktarım kanallarının doğru bir şekilde saptanması kriz dönemlerinde dışsal şoklardan kaynaklanan makroekonomik kırılganlığın etkisinin azaltılması amacıyla alınan önlemlerin etkili olabilmesi açısından önem arz etmektedir. Bir başka ifade ile finansal bir şokun, sadece kriz dönemlerinde beliren kanallarla $\mathrm{m}$ ? ya da her durumda etkili olabilecek kanallarla $\mathrm{m} 1$ aktarıldığının saptanması ekonomi yönetimi otoriteleri tarafından doğru ve etkili kriz önleme ve iyileşme mekanizmalarının tasarlanması açısından önem arz ettiği söylenebilir (Küçüksaraç vd., 2012:3).

Literatürde kriz aktarım kanalları veya mekanizmaları; faiz oranları, döviz kurları ve varlık fiyatları olmak üzere üçe ayrılmaktadır (Mishkin, 1995, Topçu vd. 2013:4). Son dönemlerde kredi kanalı da bir kriz aktarım mekanizması olarak kabul edilmektedir. Bu bağlamda Avrupa Borç Krizinin yayılmasında hangi aktarım kanallarının ön plana çıktığı sorusu ön plana çıkmaktadır. Avrupa Borç Krizi üç aktarım mekanizması vasıtasıyla etki edebilmektedir.

Bunlar; finans kanalı (aracı kurumlar ve menkul kıymet borsaları) kurtarma paketleri nedeniyle oluşan işsizlik ve döviz kuru hareketleri olarak sıralanabilir (Massa vd., 2011, Topçu vd., 2013:45). Euro Bölgesine katılan ülkeler ve genel olarak $A B$ üyesi ülkeler arasında karşılıklı dış ticaret gelişmiştir. Bu nedenle krizin yayılımında dış ticaret kanalının da etkili rol oynadığı söylenebilir.

Bir başka yönden beklentiler kanalı, finans kanalı yolu ile krizin yayılmasında önemli rol oynamıştır. Bu bağlamda beklentiler kanalı ile krizin yayılmasında Yunanistan'ın iflasının AB ve Euro Bölgesinde ortaya çıkardığı şok etkili olmuştur. Bu doğrultuda Yunanistan'ın iflasının AB ve Euro Bölgesinde ortaya çıkardığı şok ile Lehman Brothers' in iflasının küresel sistem üzerinde ortaya çıkardığı şok Küresel Finansal Kriz ve kamu borç krizinin yayılmasında benzer etkilere yol açmıştır.

\subsection{Avrupa Borç Krizinin Yayılmasında Küresel Finansal Kriz ve Yunanistan Krizlerinin Ortaya Çıkardığı Etkiler}

Yunanistan'ın krize sürüklenmesinde, Yunanistan'da yapısal reformların gerçekleştirilememesi ve diş borçlanmayla elde edilen fonların etkin kullanılamaması gibi hususların Lehman krizinin yarattığı olumsuz etkilerle birleşmesi önemli rol oynamıştır (ABGS, 2011:4). Yunanistan'ın krize 
sürüklenmesi sonrasında kamu borç krizinin $A B$ ve Euro Bölgesi geneline yayılması ile Lehman Brothers'ın iflası ile Küresel Finansal Krizin yayılması birtakım benzerliklere sahiptir.

$\mathrm{Bu}$ benzerlikler davranışsal finans kanalı çerçevesinde irdelenebilir. Davranışsal finans kanalı çerçevesinde, her iki iflasın ortaya çıkardğı risk algılarının aynı temellere dayandığı söylenebilir. $\mathrm{Bu}$ temeller Lehman Brothers ve Yunanistan'ın içinde bulundukları ekonomik ve finansal sistemler ile ilgilidir. Nihayetinde; Lehman Brothers' in iflas başvuru sonrası A.B.D' deki konut kredileri piyasasındaki krizin küresel finansal sistem üzerinde oluşturduğu risk algisı ile Yunanistan'ın iflası sonrası Euro Bölgesindeki kamu borç krizlerinin $\mathrm{AB}$ üzerinde oluşturduğu risk algısının, finansal krizin ve kamu borç krizinin bulaşıcılıkları ve yayılımında benzer etkilere yol açtığı sonucuna varılabilir (Bkz. Şekil 2).

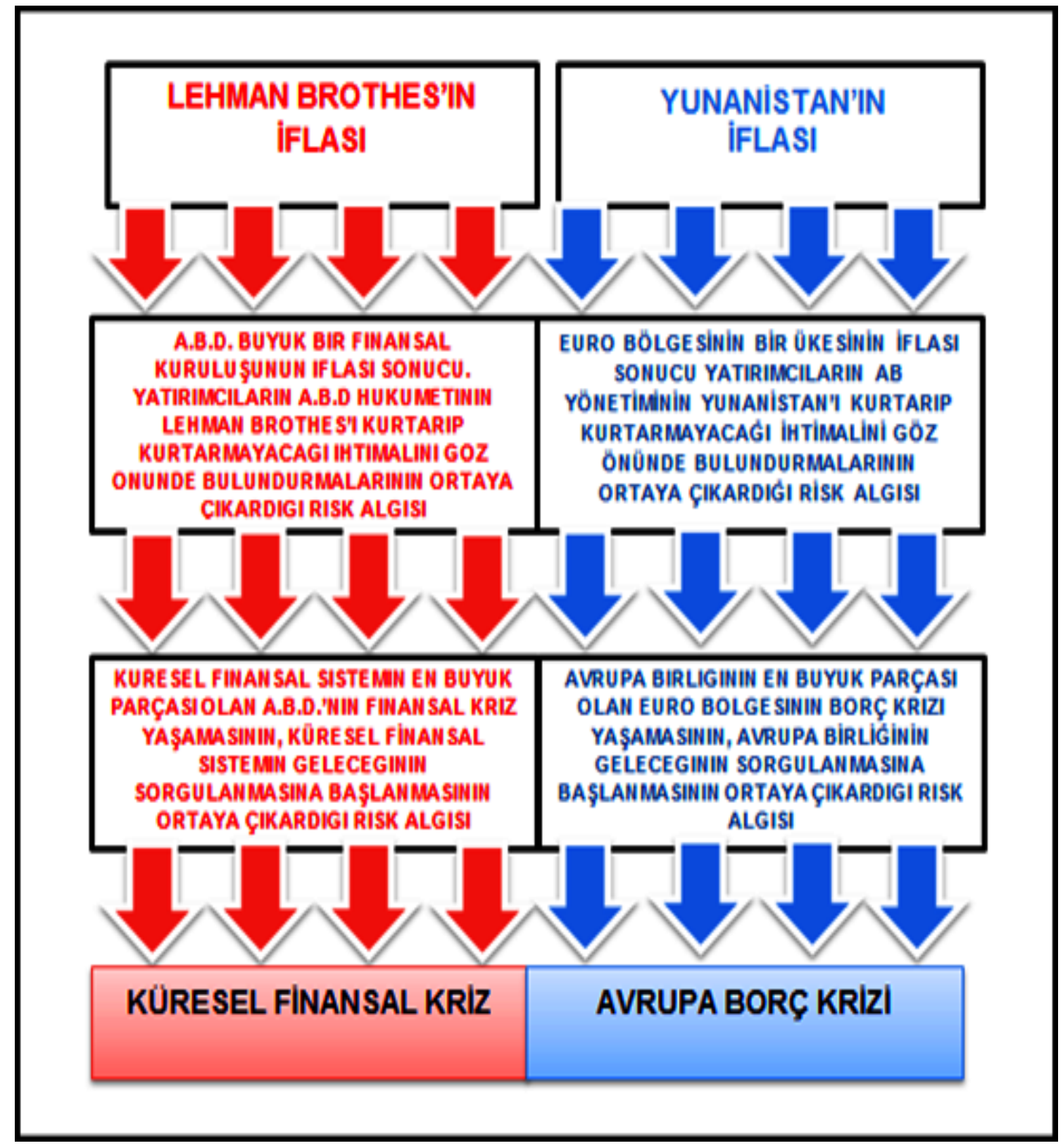

Şekil 2. Lehman Brothers ve Yunanistan'ın İflasının Ortaya Çıkardığı Risk Algılarının Nedenleri ve Sonuçları 
Lehman Brothers ve Yunanistan'ın iflası bulundukları sistemler içinde risk algılarını artırmıştır. Artan risk algıları da küresel finansal sistemi finansal krize ve $A B$ ve Euro Bölgesini kamu borç krizine sürüklemiştir. Bu doğrultuda Küresel Finansal Kriz' in Avrupa Borç Krizi'nin ortaya çıkışında hızlandırıcı etkisi olduğu söylenebilir.

Bu etki bağlamında Avrupa Borç Krizi'nin ortaya çıkış sürecinde Küresel Finansal Kriz merkezli dış şok etkili olmuştur. Literatürde Lehman Krizi olarak da isimlendiren Küresel Finansal Kriz tüm küresel sistemi olduğu gibi Euro Bölgesi ve $A B^{\prime}$ yi bir bütün olarak olumsuz bir şekilde etkilemiştir. Küresel Finansal Krizin olumsuz etkileri Euro Bölgesinde makroekonomik kırılganlıkları olan ülkeler üzerinde daha fazla olmuştur.

Euro Bölgesinin en fazla makroekonomik kırılganlıklara sahip ülkeleri PIIGS ülkeleridir. Avrupa Borç Krizinin bulaşıcılığı ve yayılmasında Euro Bölgesinde makroekonomik kırılganlıklar önemli rol oynamıştır. Avrupa Borç Krizinin Euro Bölgesinde yer alan ülkelerin makroekonomik yönden zayıflık ve kırılganlık derecesine göre seçici etki yaparak yayıldığı ifade edilebilir. Küresel Finansal Krizin küresel etki yapan akut bir kriz, Avrupa Borç Krizinin ise seçici etki yapan kronik $\begin{array}{llll}\text { bir kriz olduğu } & \text { sonucuna }\end{array}$ http://www.tcmb.gov.tr/yeni/duyuru/2012/Baskan_SDE.php, Erişim Tarihi, 05.05.2013).

Avrupa Borç Krizinin seçici etkisi ve kronik yapısı doğrultusunda, krizin başlangıcından bu yana Avrupa Borç Krizinin derinleştiği ülkelerde krizin diğer gelişmekte olan ülkelere göre daha uzun süreli olduğu görülmüştür (Küçüksaraç vd., 2013:7). Krizin yayılmasının analizinde makroekonomik kırılganlığı en yüksek olan ülke ve ülkelerin tespit edilmesi önem arz etmektedir. Bu doğrultuda PIIGS ülkeleri arasında makroekonomik kırılganlığı en yüksek olan ülke Yunanistan'dır (Kaya vd., 2011:4). ${ }^{2}$

Ülkelerin makroekonomik kırılganlıklarına göre seçici etki yapan ve kronik bir kriz olan Avrupa Borç Krizinin, ekonomisinin kırılganlık derecesi deneysel olarak da test edilen Yunanistan'da başlayıp en fazla bu ülkede derinleşmiştir. Sonrasında ise bu ülkeden çeşitli kanallar vasıtası ile makroekonomik kırılganlıkları yüksek olan diğer PIIGS ülkelerine bulaşması ve yayılmasında $\mathrm{AB}$ piyasalarındaki genel panik havası etkili rol oynamıştır.

$\mathrm{Bu}$ çerçevede ilk olarak İfade edilebilecek husus bir $\mathrm{AB}$ ve Euro Bölgesi ülkesi olarak Yunanistan'ın iflasının, $A B$ ve Euro Bölgesi piyasalarında $A B$ ve Euro Bölgesinin geleceğine ilişkin soru işaretleri ortaya çıkarması kaynaklı artan sistemik risktir. Devamında bu riski tetikleyen başka gelişmelerde yaşanmıştır. Bunlardan en çok öne çıan $A B$ yönetiminin krize reaksiyon göstermede geç ve yetersiz kalmasıdır. $A B$ yönetiminin krizden çıkılması için sonradan gösterdiği reaksiyonlar ise krizi çözümüne ve yayılmasına negatif etki yapmıştır.

\subsection{AB Ekonomi Yönetiminin Avrupa Borç Krizinin Yayılmasındaki Rolü}

AB yönetimi Mayıs 2010'a kadar Yunanistan'daki krize reaksiyon göstermede yetersiz kalması piyasalarda panik havasını daha da artırmıştır. Ortaya çıkan panik havası içerisinde $A B$ yönetiminin sorunun çözümüne nasıl yaklaşacağına ilişkin beklentilerin etkileri, Yunanistan'ın makroekonomik verilerini revize etmesi ve borçlarının ödeyemeyeceğini ilan etmesinin etkisine kıyasla daha fazla rol oynamıştır.

$A B$ ve Euro Bölgesi yatırımcıları Yunanistan'dan krizin yapısına ilişkin açıklamalardan ziyade $A B$ yönetiminin Yunanistan Krizi'nin çözümünde uygulayacağı politika çerçevesine ilişkin açıklamalara odaklanmışır. Bir bakıma piyasalar Yunanistan'ın kamu borçları ve

${ }^{2}$ Kaya vd (2011). yapılan çalışmada kırılganlık endeksi oluşturulmuştur. PIIGS ülkeleri ile beraber Belçika'nın kırılganlı̆̆ test edilmiştir. Bu çalışmanın sonucunda Yunanistan'ın PIIGS ülkeleri içinde kırılganlığı en yüksek ülke olduğu sonucu ortaya çıkmıştır. 
makroekonomik verilerine ilişkin açıklamalardan daha fazla $A B$ yönetiminin kriz ve krizin çözümüne ilişkin açıklamalarını fiyatlamışlardır (Mink ve Haan, 2013:111).

Bu fiyatlamalar sonrasında yatırımcılar Yunanistan'ın borçlanma kâğıtlarını riskli algılamaları, bu kâğıtların faizlerini daha fazla yükseltmiştir. Artan faizler sonrası Yunanistan'la benzer makroekonomik görünüme sahip ülkelerde yatırımcılar tarafından riskli olarak algılanmaya başlamıştır. Bu çerçevede bu ülkelerin borçlanma kâğıtlarının faizleri de artmaya başlamıştır. Artan faizlerde yatırımcılar nezdinde bu ülkelerinde Yunanistan gibi borçlarını ödeyemeyebileceği algısını ortaya çıkarmıştır. Böylece, piyasalarda bu ülkelerin kamu borç krizi yaşayabilme ihtimali sorgulanmaya başlanmıştır. Bu ihtimal literatürde yer alan kamu borç krizlerinin kendi kendini gerçekleştirmesi teorisinin $A B$ ve Euro Bölgesi ölçeğinde gerçekleşmesine neden olmuştur.

\subsection{Kamu Borç Krizlerinin Bulaşıcılık ve Yayılma Derecesinin Yüksek Olması}

Literatürde kamu borç krizlerinin kendi kendini gerçekleştirme özelliğine sahip olup olmadıkları tartışılagelmektedir (Chamon, 2007). Bir başka ifade ile bu teori, bir ülkenin kamu borç krizi yaşayabileceğine ilişkin piyasalarda oluşabilecek bir algının; ülkenin borçlanma araçlarının maliyetlerini artış trendine sürükleyerek ülkenin makroekonomik görünümünü borçlarının anapara ve faiz ödemelerini yapamayacak konuma sürüklemesi olarak özetlenebilir. Bu bağlamda Yunanistan krizi ile Yunanistan'dan PIIGS ülkelerine doğru bir kamu borcu spirali ortaya çıkmıştır.

Yunanistan krizi borç stoku yüksek olan diğer PIIGS ülkelerinin finansmana ulaşmasını daha maliyetli hale getirerek bir borç spirali ortaya çıkarmıştır. Bir bakıma, yatırımcıların 'Yunanistan'da olan niçin İspanya ya da İtalya'da da olmasın' düşüncesini benimsedikleri söylenebilir. $\mathrm{Bu}$ durum $\mathrm{AB}$ ve Euro Bölgesinde devlet tahvil faizlerini yükseltmiştir. Bu yükseliş, normal şartlar altında borçlarını çevirebilecek konumdaki ülkelerin ortaya çıkan panik havası nedeni ile borcunu çeviremez duruma gelmesine yol açmıştır. Bir bakıma literatürde kendi kendini gerçekleştirme (Self-Fulfilling Prophecy) olarak bilinen kısır bir kriz döngüsünün başlatmıştır (Usak, 2011:25).

$\mathrm{Bu}$ döngüyü başka gelişmelerde tetiklemiştir. Bunlardan biri $\mathrm{AB}$ yönetimin kamu borcu spirali ve bu kısır kriz döngüsünün $A B$ ve Euro Bölgesinde ortaya çıkma ihtimalini görmezden gelerek Yunanistan'a yardım konusunda istekli davranmamasıdır. AB yönetiminin bu isteksiz tavrı piyasaların Euro'nun sahipsiz bırakıldığı algısını fiyatlamasına yol açmıştır (Paul De Grauwe,2010,Usak,2011: 26). Ortaya çıkan bu algı Yunanistan ile benzer makroekonomik görünüme sahip diğer PIIGS ülkelerinin borçlarını ödemekte zorlanabileceği algısını yatırımcılar nezdinde daha fazla kuvvetlendirmiştir.

\subsection{Avrupa Borç Krizinin Yayılmasında Euro Bölgesi Ülkelerinin İhraç Ettikleri Borçlanma Araçlarının Rolü}

$\mathrm{AB}^{\prime}$ nin toplam üretiminin \%2'sini karşılayan Yunanistan gibi ekonomisi küçük bir ülkenin kriz yaşamasının, $\mathrm{AB}$ ve Euro Bölgesi yatırımcılarının diğer ülkeleri de krize sokacak kadar büyük bir paniğe kapılmasına neden olarak $A B$ ve Euro Bölgesini krize sürüklediği sorusunu akıllara getirmiştir (Ergin, 2013). Bu sorunun cevabı ise başta Yunanistan'ın ihraç ettiği devlet tahvillerinin hangi ülkelerin bankaları bilançolarında tutulduğu ile verilebilir (Bkz. Şekil 3.). 


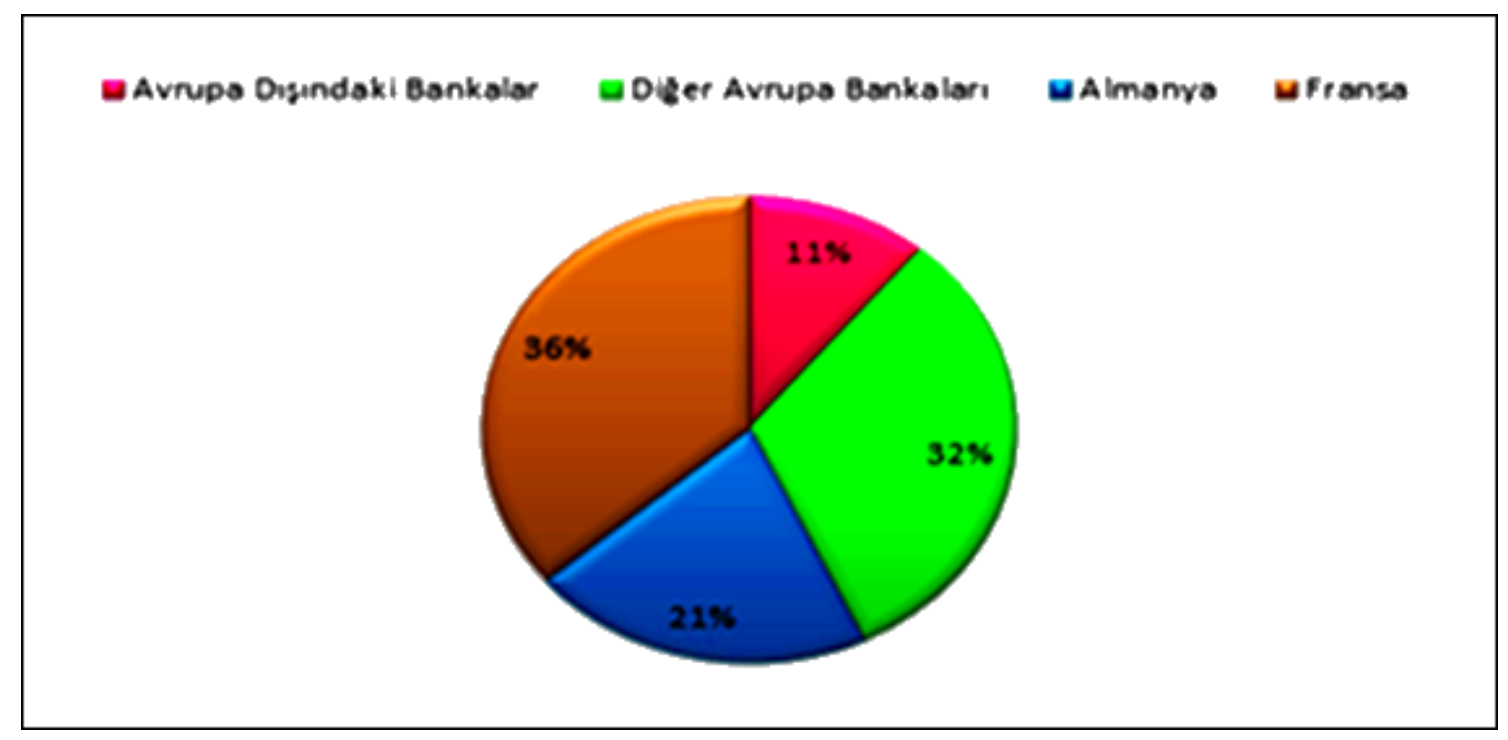

Şekil 3. 2009 Yılı Verileri İle Yunanistan'ın İhraç Ettiği Devlet Tahvillerinin Bilançolarında Bulunduran Ülkelerin Yüzdesi

Kaynak: IMF,2012: 208, Ergin 2013:150

Görüldüğü üzere Yunanistan'ın devlet tahvillerinin toplamda \% 89 ‘u AB içerisinde yer alan bankaların bilançolarında bulunmaktadır. Yine toplamda \%57'lik kısmı ise birliğin lokomotif ülkeleri olan Almanya ve Fransa'nın bankaları bilançolarında yer aldığı görülmektedir. Yunanistan'ın iflasının Yunan devlet tahvillerinin geri ödenmeme riskini artırması, özellikle Almanya ve Fransa'daki bankaların bilançolarında bozulmaya yol açmıştır. Bilançolarda ortaya çıkan bozulma sonrası AB ve Euro Bölgesi bankacılık sektöründe sistemik risk artmıştır.

Artan sistemik risk sonrası yatırımcılar kamu borçlarının reel GSYiH' ya oranı göstergesinde benzer yapıda olan diğer Euro Bölgesi ülkelerinin devlet tahvillerini de Yunanistan devlet tahvilleri çerçevesinde fiyatlamaya başlamışlardır. Daha somut bir ifade ile ülkelerin Yunanistan'daki kriz öncesi Euro cinsinden borçlanma maliyetleri Alman Markına yaklaşırken, Yunanistan krizi ile borçlanma maliyetleri Yunan Drahmisine yaklaşmaya başlamıştır (Dağdelen,2011: 3,http://www.businessweek.com/news/2010-05-14/euro-breakup-talk increasesas-germany-loses-proxy-update1-.html, Erişim Tarihi,12.10.2013).

Borçlanma maliyetlerindeki yükselme sonrası makroekonomik görünümü Yunanistan'a en benzer Euro Bölgesi ülkesi olan Portekiz de kamu borcu krizinin ortaya çıkma olasılığı artmıştır. $\mathrm{Bu}$ olasılık güncel hayatta gerçek kişiler arasında gerçekleşen borç ilişkilerine benzetilerek ele alınabilir.3 Devamında bu olasılık Portekiz de kamu borç krizi ortaya çıarmıştır

\footnotetext{
${ }^{3}$ Örneğin; Ortak A, B,C olmak üzere üç tane ortağı olan bir şahıs şirketi olsun. Bu her üç ortağında "X" bankasından \%25 faizli kredi kullandığını düşünelim. Ortakların aylık kazançları sırasıyla 100000, 110000, 350000 lira olsun. Üçüncü kişilere olan toplam borçları sırasıyla 50000, 52000 ve 1000 lira olsun. Ortaklardan A alacaklılarına "kişisel harcamalarımı takip ederken yaptığım yanlış hesaplamalar nedeniyle, sahip olduğum varlıklarımın, yükümlülüklerimi karşılayamadığını görmekteyim. Bu nedenle size olan borçlarımı ödeyemeyeceğim" faksını çeksin. Bu faksı okuyan alacaklı X bankası ortak B' nin toplam borcunun ve aylık kazancının ortak A'ya çok yakın seviyelerde olduğunu bilmektedir. Ortak B tekrar X bankasına kredi başvurusu yapar. Ancak banka ortak B'nin durumunun iflas eden A'ya benzemesinden ötürü bu sefer $\% 45$ faiz oranından kredi açabileceğini ifade eder. Çünkü $A^{\prime}$ dan istenen faiz oranı iflas etmesinden ötürü \% 50'ye yükselmiştir. Ortak B A'ya benzediği için onun borçlanma maliyeti de ortak A'nın borçlanma maliyetine yakınsamıştır. Ortak B artan borçlanma maliyeti sonucu borçlarını yine borçla çevirememeye başlar. Çünkü artık borçlarının faiz ödemelerini yapamamaktadır. En sonunda adi şirketin
} 
Bu bağlamda Yunanistan'ın ve Portekiz'in temerrüde düşmesi; $A B$ bankalarının $A B$ 'nin toplam borcunun \%3.3' üne tekabül eden yükümlülüklerini karşılayamayacakları gerçeğini ortaya çıkarmıştır (Nemeth, 2012:4).

Euro Bölgesi Bankacılık sektörü Euro Bölgesi ülkelerinin borçlanmak amacıyla ihraç ettiği finansal araçları kayda değer bir oranda bilançolarında bulundurmaktadır. Bu durum ise, Euro Bölgesinde kamu borçlarının riskinin Euro Bölgesi bankacılık sektörüne aktarımında önemli rol oynamıştır (Roman ve Bilan, 2012:166). Bu çerçevede bankalarda kalıcı likidite sorunları baş göstermeye başlamıştır. Bu durum Euro Bölgesi merkez bankalarını Euro sistem ${ }^{4}$ içerisinden borçlanmaya zorlamıştır (Lapavitas vd, 2010: 51-52). Sonuçta, Euro Bölgesi ülkeleri bankacilık sektörleri arasındaki karşılıklı yükümlülükler artmıştır (Bkz. Şekil 4). (Değerli ve Keleş., 2011:6).

\begin{tabular}{|lcccc|}
\hline & Almanya & Fransa & Italya & Ispanya \\
\hline a.Almanya & - & 253 & 266 & 59 \\
b.Fransa & 207 & - & 41 & 29 \\
c.Italya & 165 & 405 & - & 35 \\
d.Ispanya & 178 & 147 & 32 & - \\
e.Inanda & 117 & 38 & 14 & 11 \\
f.Portekiz & 39 & 29 & 4 & 90 \\
g.Yunanistan & 36 & 53 & 5 & 1 \\
$c+f+g$ & 239 & 486 & 9 & 126 \\
$c+d+f+g$ & 417 & 633 & 41 & 126 \\
$c+d+e+f+g$ & 534 & 671 & 55 & 137 \\
\hline
\end{tabular}

Şekil 4. Euro Bölgesi Ülkeleri Bankacılık Sektörleri Karşılıklı Yükümlülükleri (Milyar ABD Doları, Mart 2011 itibarıla).

Kaynak: BIS, Değerli ve Keleş, 2011:6

Borç krizinin yayılmasında bir başka önemli husus ise PIIGS ülkelerinin toplam kamu borçlarının kendi aralarında ve $\mathrm{AB}^{\prime}$ nin lokomotif ülkelerine olan dağılımıdır (Usak, 2011: 24). (Bkz. Şekil 5).

diğer ortağ $1 \mathrm{C} X$ bankasına kredi başvurusu yapar. A ve B iflas etmeden önce $\mathrm{X}$ bankası C'den \%15 faiz istemekte idi. Ancak Banka C'nin A ve B ile adi ortaklık ilişsisinde olmasını bir risk unsuru olarak görmektedir. Bu nedenle C'den \% 15 değil \%20 faiz talep eder. Görüldüğü üzere ortak B borçlarını çevirebilecek konumda iken adi ortaklık ilişkisi içinde olduğu A'nın iflası nedeniyle borçları çevirememiştir. Ortak C'nin ise çok iyi durumda olmasına rağmen A ve B ile adi ortaklık ilişkisi sonucu borçlanma maliyeti yükselmiştir.

${ }^{4}$ Euro Bölgesine katılan ülkelerin merkez bankaları ile birlikte Avrupa Merkez Bankasının yer aldığı merkez banları sistemine verilen isimdir. 


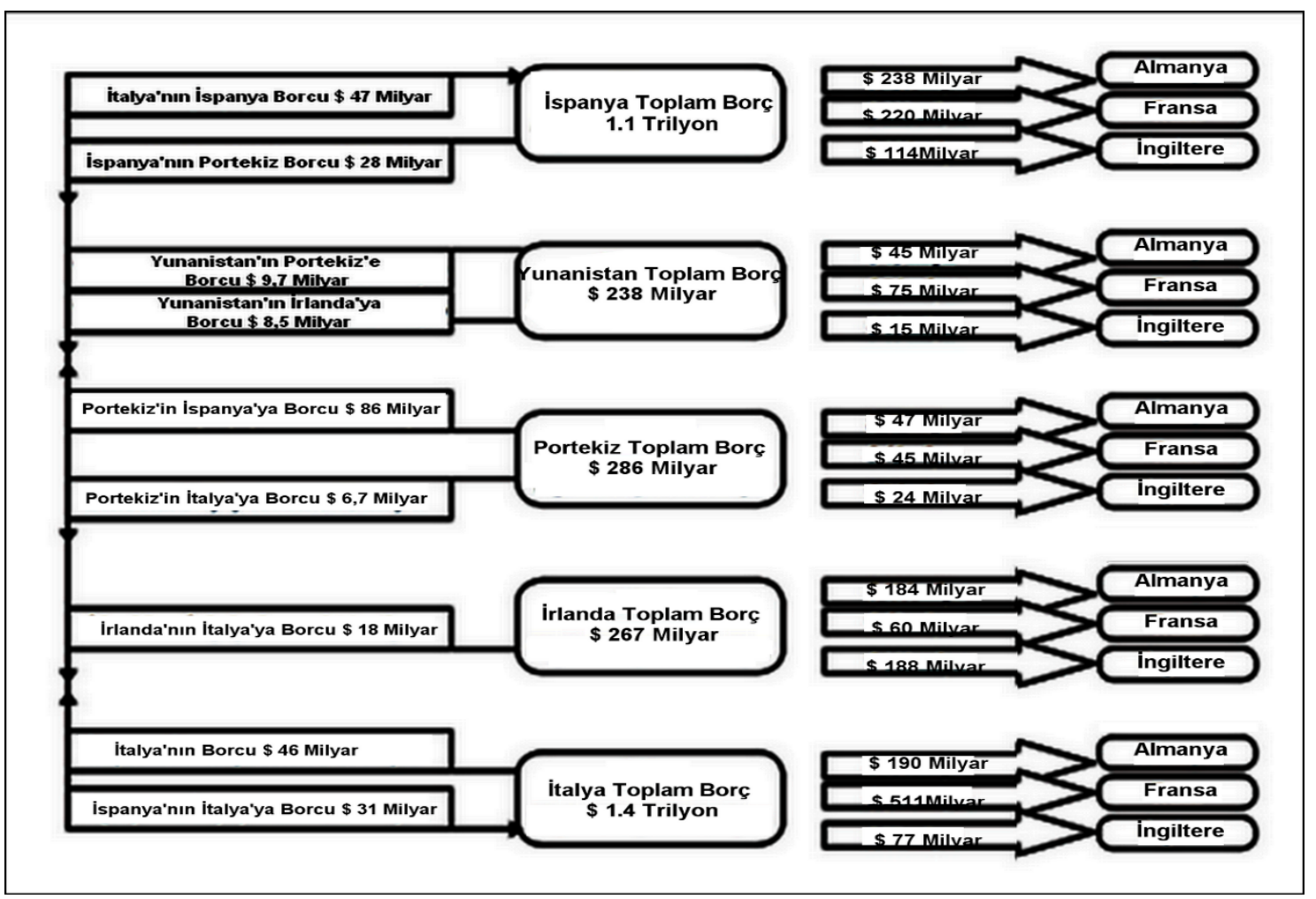

Şekil 5. Euro Bölgesinde Merkez ve Çevre Ülkelerinin Birbirlerine Olan Karşılıklı Borçları

Kaynak: BIS, 31.12.2009, Usak, 2011: 24

Görüldüğü üzere $\mathrm{AB}$ ekonomilerinin ağırlıklı olarak birbirlerinden borçlandıkları görülmektedir. $\mathrm{Bu}$ durum kreditörlerin, özellikle de bankaların yaşayacağı mali bünye sorunlarının $\mathrm{AB}$ ve Euro Bölgesi ekonomileri için bir tehdit ortaya çıkarmaktadır. Bu tehdit, $\mathrm{AB}$ ekonomi yönetiminin finansal sistemi kurtarmak için devasa maliyetler yüklenmek zorunda kalabileceği ihtimalini kuvvetlendirmiştir (Sezgin, 2012:147).

$\mathrm{Bu}$ çerçevede Euro Bölgesi'ne hakim olan genel düşünce, kamu borçlarının ödenmesi için Yunanistan'a $\mathrm{AB}$ tarafından yardım yapılmamasının gerektiği yönünde oluşmasına rağmen; Yunanistan'ın kamu borçlarını ödeme konusunda moratoryum ilan etmesi durumunda bile, Euro Bölgesi bankacılık sistemine ve diğer üye ülkelere kontrol edilemeyecek ekstra bir yük getirmeyeceği inancı hakim olmuştur. Bununla birlikte, kurtarma politikalarına karşı oluşan bu yaklaşımlar, Nisan 2010 sonlarına doğru Portekiz'den sonra ve İspanya devlet tahvillerinin risk primlerinin hızlı bir şekilde artması sonucu değişmeye başlamıştır (Şanlığlu ve Bilginoğlu, 2010:159).

2010 yılı bahar aylarında Yunanistan'ın borç geri ödemelerinde karşılaştı ğı sorunlar, başta PIIGS ülkeleri olmak üzere diğer bazı Euro Bölgesi ülkelerini de direkt olarak olumsuz bir şekilde etkilemeye başlamış ve bu durum Yunanistan'a mali yardımların yapılması zorunluluğunun ortaya çıkmasına neden olmuştur (Şanlığlu ve Bilginoğlu, 2010:159). Bu bağlamda AB yönetimi 2 Mayıs 2010 tarihinde Yunanistan için kurtarma paketini onaylamıştır. Kurtarma paketinin onayı başlangıçta Euro Bölgesinde devlet tahvilleri piyasası üzerinde olumlu bir etki yapmıştır. Ancak kısa bir süre sonra Yunanistan'ın CDS primleri tekrar yükselmeye başlamıştır (Bkz. Şekil 6). 


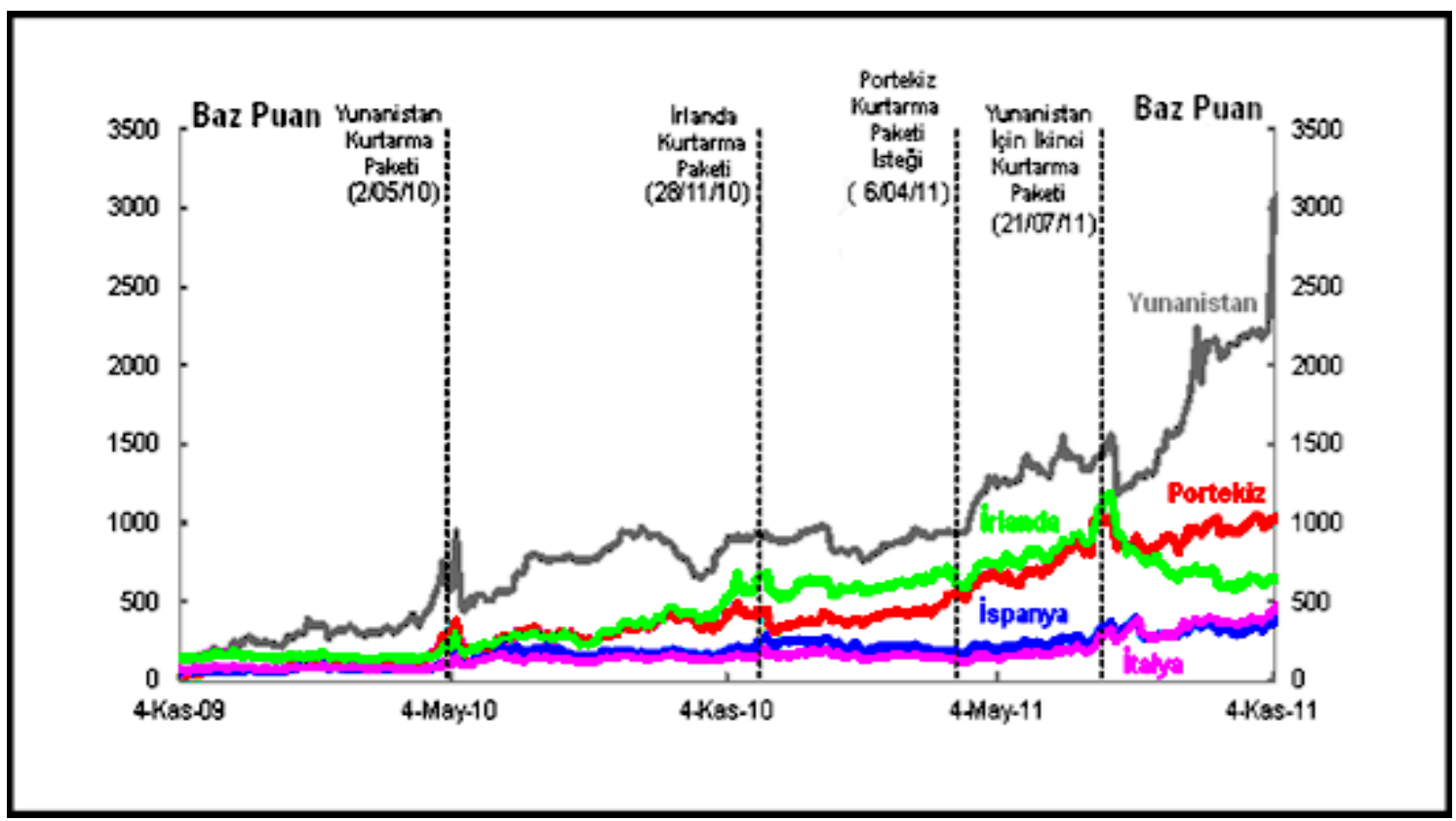

Şekil 6. Kurtarma Paketleri Sonrası PIIGS Ülkeleri Kamu Borçları Geri Ödenmeme Riski (CDS) Yayılımı

Kaynak: Thompson Reuters' dan uyarlanmıştır.

Yunanistan'ın devlet tahvillerinin geri ödenmeme riski olan CDS primlerinin tekrardan artmaya başlaması; diğer benzer makroekonomik görünüme sahip PIIGS ülkelerinin CDS primlerini yükseltmeye başlamıştır (Bkz. Şekil 6).

Yunanistan kurtarma paketi sonrasında Yunanistan'ın CDS primleri yükselmeye başlamış ve bu yükselişle diğer PIIGS ülkelerinin de CDS primleri ve 10 yıllık tahvil faizleri artmaya başlamıştır. $\mathrm{Bu}$ artış; kurtarma paketinin yatırımcılar tarafından nasıl fiyatlandığı sorusu çerçevesinde irdelenebilir.

$\mathrm{AB}$ yönetimince Yunanistan için 110 milyar Euro tutarında devasa kurtarma paketinin onaylanması; yatırımcılar nezdinde Euro Bölgesinin geleceğine ilişkin ki kuşkuları daha da artırmıştır. Yunanistan krizinin başlangıç evrelerinde $A B$ yönetiminin krizin çözülmüne lişkin isteksiz davranması, Euro Bölgesinin geleceğine ilişkin kuşkuları artırmıştır. Artan kuşkular sonucu $\mathrm{AB}$ yönetiminin Yunanistan için devasa bir kurtarma paketini onaylaması, yatırımcıların bu seferde Euro Bölgesi ve $A B^{\prime}$ nin dağılmasına kadar sonuçları ağır olabilecek ciddi bir krizle karşı karşıya kalındığı algısını fiyatlamalarına neden olmuştur. Bir başka ifade ile Euro Bölgesinde başta Yunanistan'ın CDS primleri olmak üzere PIIGS ülkelerinin CDS primlerinin spillover (yayılma) etkisi artarak kamu borcu spirali oluşturmaya başlamıştır (Ergin, 2013). (ABGS, 2011).

Oluşan kamu borcu spirali ile Yunanistan'da başlayan kriz artık Euro Bölgesine yayılmaya başlamıştır. Bu yayılma neticesinde Yunanistan ve Portekiz'den sonra İrlanda' da kamu borçlarını çevirmez konuma sürüklenmiştir. Bir başka ifade ile Yunanistan krizi il olarak, İrlanda ve Portekiz'e aktarım kanallarının kriz döneminde etkin çalışması ile bulaşarak yayılmıştır.

Krizin yayılması sonrası diğer PIIGS ülkelerinin yükümlülüklerinin hangi ülkelerin bankalarının bilançolarında yer aldığı kamu borç krizinin bundan sonraki aşamaları açısından önem arz etmeye başlamıştır. Bu bağlamda, 2010 yılı verileri itibari ile diğer PIIGS ülkelerinin, yabancı bankalara olan toplam yükümlülükleri incelediğinde yine Yunanistan'la benzer bir tablo ile 
karşılaşılmaktadır. Çünkü diğer PIIGS ülkelerinin yabancı bankalara olan yükümlülükleri içerisinde yine Almanya ve Fransa bankaları ağırlıktadır (Bkz. Şekil 7).

Krizin bu ülkelere bulaşması düşük sermaye yeterliliği ve yüksek kaldıraç oranları ile çalışan ve Yunanistan'ın iflası ile riski yüksek olan $\mathrm{AB}$ bankacılık sektöründe krizin etkilerini daha da derinleşmiştir.

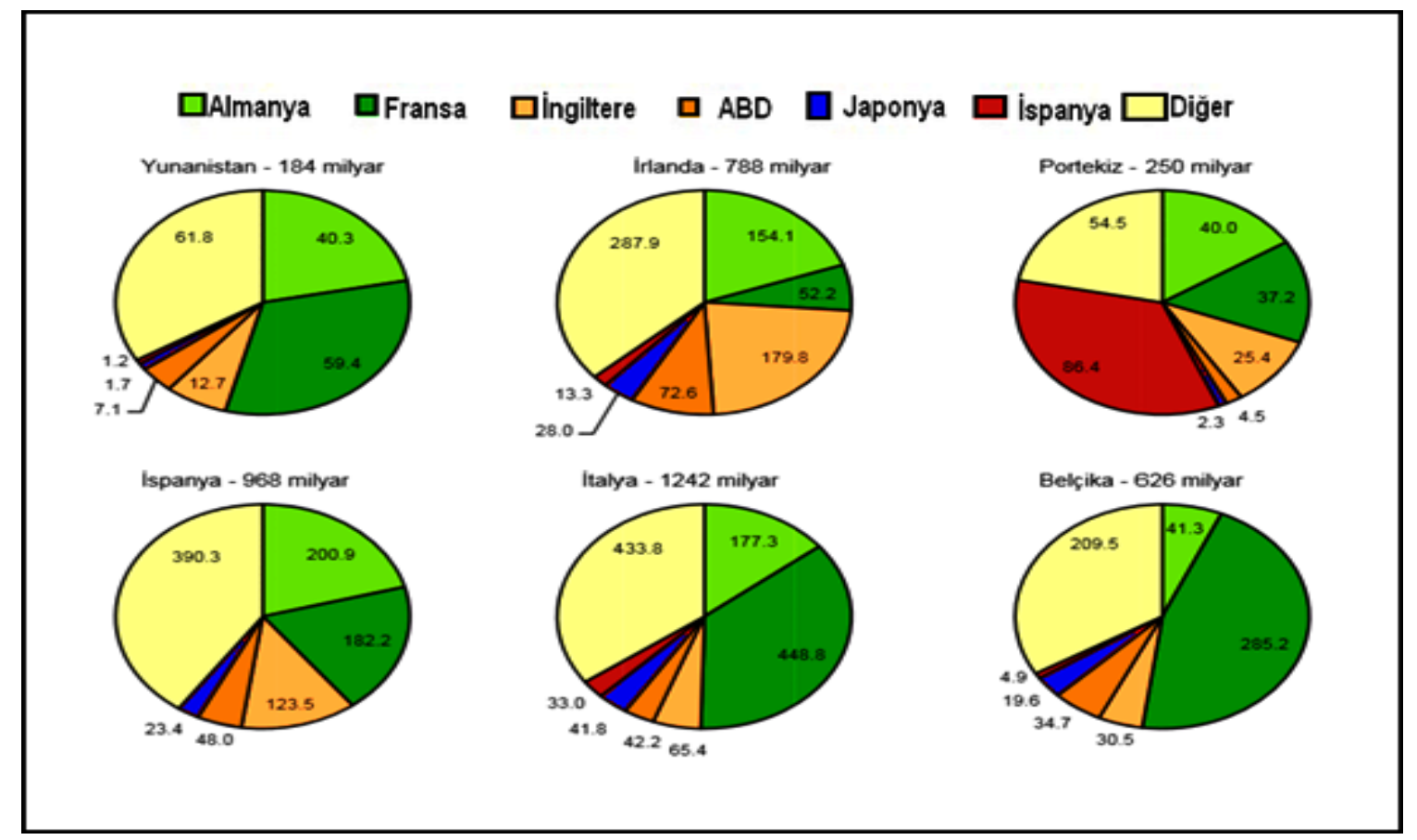

Şekil 7. Euro Bölgesi Çevre Ülkeleri Bankacılık Sektörlerinin Yabancı Bankalara Olan Yükümlülükleri ( Brüt ABD Doları Eylül 2010 İtibarı ile)

Kaynak: BIS, Kaya vd., 2011: 5 ‘den uyarlanmıştır.

$\mathrm{Bu}$ bağlamda $\mathrm{AB}$ ve Euro Bölgesi bankacılık sektörünün neden PIIGS ülkelerinin kağıtlarına yatırım yaptığ 1 sorusu ön plana çıkmıştır. Bu soru risk ve getiri arasındaki ilişki çerçevesinde irdelenebilir. Bu doğrultuda Küresel Finansal Kriz öncesi, Euro Bölgesi Merkez ülkelerinde likiditenin bolluğu yaşanmıştır. Merkez ülkelerinin bankacılık sektörü bu likiditeyi çevre ülkelerinin borçlanma araçlarına yatırarak likiditenin getirisini artırmak istemişlerdir. Borçlanma araçlarında da devlet tahvilleri ön plana çıkmıştır. Bu bağlamda devlet tahvillerinin Basel kriterlerine göre risksiz kabul edilmesi, özel sektör tahvillerine kıyasla devletlerin ödeme garantisinin oluşu ve paraya çevrilmesinin kolay olması merkez ülkeleri bankalarını, çevre ülkelerinin düşük faiz oranlarından fazla sayıda ihraç ettiği devlet tahvillerine yatırım yapmaya yöneltmiştir. Buradan ortaya çıkan sonuç krizin yayılması ve bulaşıcılığında devlet tahvillerinin riskinin önemli rol oynadığıdır.

Bu kapsamda devlet tahvillerinin riskinin bulaşıcıllğg incelenebilir. Bulaşıcılık analizleri için genel kabul gören yaklaşımda bulaşıcllık; kriz dönemleri finansal getirilerin oynaklığının yüksek olduğu dönemler olarak ifade edilmektedir (Küçüksaraç vd., 2013:7). Yunanistan krizinde devlet tahvillerinin risk primlerinin bulaşıcılığ bu yaklaşım çerçevesinde irdelenebilir.

Constancio,(2012)5 yaptığı çalışmada 2009-2011 yılları arasında Yunanistan devlet tahvil getirilerinin Portekiz ve İrlanda'nın devlet tahvil getirilerine olan bulaşıcllık etkisini kredi riski

\footnotetext{
${ }^{5}$ Vitor,Constancio,Avrupa Merkez Bankası başkan yardımcısı.
} 
yaklaşımı ile incelemiştir. Bu dönemde Yunanistan devlet tahvil getirilerinin, Portekiz ve İrlanda devlet tahvil getirilerine bulaşıcıllk etkisinin $\% 25$ ve $\% 45$ aralığında saptamıştır. ${ }^{6}$ (Constancio,2012:113). Yunanistan tahvil getirilerinin Portekiz ve İrlanda tahvillerine bulaşma derecesinin yüksek olması bu ülkelerin borçlarını çevirmesini daha da zorlaştırmıştır.

Bu bağlamda $\mathrm{AB}$ yönetimi sırasıyla İrlanda ve Portekiz için de kurtarma paketlerini onaylamıştır. Bu kurtarma paketleri de aynı Yunanistan için onaylanan kurtarma paketinde olduğu gibi ilk olarak kısa bir süre Euro Bölgesinde riski düşürmüş daha sonra ilk duruma göre aynı nedenlerden ötürü daha çok yükseltmiştir (Bkz. Şekil 6).

Constancio (2012) yine aynı çalışmasında, Yunanistan, İrlanda ve Portekiz devlet tahvil getirilerinin, İtalya ve İspanya devlet tahvil getirileri üzerine bulaşma etkisini incelemiştir. Ortaya çıkan sonuçlara göre, 2009-2011 arası dönemde, Yunanistan, İrlanda ve Portekiz'in devlet tahvil getirilerinin İtalya' nın devlet tahvil getirilerini yaklaşık olarak ortalama hesaplama ile \%38, İspanya'nın ise \%33 etkilediği sonuçlarına ulaşmıştır. Yine bu doğrultuda, 5 Temmuz 2011 tarihinde Moody' nin Portekiz'in kredi notunu indirmesi ile birlikte Yunanistan'in temerrüde düşmesi kaygıları; bu süreçte İtalya ve İspanya'nın ekonomilerine ilişkin herhangi bir olumsuz veri açıklanmamasına rağmen İspanya ve İtalya'nın devlet tahvil faizlerini artırmıştır. Bu durumda Yunanistan özel sektörünün bulaşıcılık etkisinde rol oynamıştır Ancak İspanya ve İtalya'nın pozisyonları 2011 sonu ve 2012 yılı başlangıcı itibariyle iyileşme göstermiştir (Constancio,2012:113).

Euro Bölgesinde CDS primlerinin daha da artması Yunanistan'ın borçlarını çevirmesini daha da zorlaştırmıştır. $\mathrm{Bu}$ nedenle $\mathrm{AB}$ yönetimi 21 Temmuz 2011 tarihinde Yunanistan için ikinci kurtarma paketini onaylamıştır. Yunanistan'a ikinci kurtarma paketinin onaylanmasından sonra PIIGS ülkeleri CDS primleri farklı yönlerde hareket etmeye başlamıştır (Bkz., Şekil 6). Bu farklı yönlerdeki hareketlerin ve İspanya ve İtalya'nın pozisyonlarının düzelmeye başlamasının nedenleri "Euro Bölgesinde Ortaya Çıkan Kamu Borçlarının Sürdürülebilirliği" kısmında irdelenmeye çalışılmıştır.

\subsection{Avrupa Borç Krizinin Yayılması İle PIIGS Ülkelerinde Kamu Borçlarının Sürdürülebilirliği}

Euro Bölgesinde PIIGS ülkelerinin artan kamu borçları ve bu borçların sürdürülebilirlik düzeyinin tespiti krizin daha da derinleşmesini ve kronikleşmesini önlemede önem arz etmektedir. Değerli ve Keleş (2011) tarafından yapılan çalışmada Euro Bölgesi PIIGS ülkelerinin kamu borçlarının sürdürülebilirliği standart borç dinamiği denklemi ile incelenmiştir.

Çıkan sonuçlara göre Yunanistan, Portekiz ve İrlanda'nın borçlarını piyasa faizleri ile çevirebilmesi için faiz dışı fazla dengesinde kayda değer bir ilerleme sağlamaları gerektiği sonucu ortaya çıkmıştır. İtalya'nın ise kısa vadede borçlarını çevirmede sıkıntısı olmadığı saptanmıştır. Bununla birlikte, İtalya'nın borçlarının faiz seviyesine duyarlı olması ve orta vadede borçların çevrilmesinde sorun yaşaması nedenlerinden ötürü piyasaların İtalya'yı da riskli ülkeler sınıfında algılamasına neden olmuştur. İspanya ise kamu maliyesindeki problemlerin en düşük çıktı̆̆ ülke olmuştur (Değerli ve Keleş, 2011:3-4).

\footnotetext{
${ }^{6}$ Vitor Constancio yaptığı çalışmada yalnızca Portekiz’e ilişkin sonuçları vermiş İrlanda'ya ilişkin durumunda yaklaşık olarak aynı yönde olduğunu vurgulamıştır.
} 


\section{SONUÇ}

1999 yılında kurulan ve 2002 yılında tek para uygulamasının başlamasını sağlayan Avrupa Para Birliği'nin veya bir diğer adı ile Euro Bölgesi'nin kurulması Avrupa Borç Krizinin ortaya çıkışında önemli rol oynamıştır. Euro Bölgesinin kurulması AB'nin uzun vadede amaçları ile yakından ilgilidir. $A B^{\prime}$ nin uzun vadede amacı, bir ekonomik ve siyasi birliğe dönüşmektedir. $A B$ bu dönüşümü sağlayacak mekanizmalara ihtiyaç duymaktadır. Parasal birliğin sağlanmasının bu mekanizmalardan biri olduğu vurgulanabilir.

Parasal birliğin tasarımı siyasi birliği sağlamada bir basamak ve mekanizma olmasının yanı sıra, $\mathrm{AB}$ içerisinde ekonomisi zayıf olan ülkelerin kalkındırılması amacıyla yapılandırılan bir büyüme modeli olarak ortaya çıkmaktadır. Ancak bu büyüme modelinin tasarımı hatalı yapılmıştır. Daha doğrusu zayıf ekonomilerin tek para uygulaması içerisinde yer alması tek para uygulamasının gerçekleştirilebilmesi koşullarına aykırılık teşkil etmektedir. Çünkü tek para uygulamasının teorik yapısı olan Optimum Para Alanı teorisinde tek para uygulamasına katılacak ülkelerin benzer makroekonomik görünüme sahip olmaları gerekmektedir. En başından zayıf makroekonomik yapıya sahip ülkelerin para alanına dâhil edilmesi para alanı uygulamasının başarısız olmasına neden olmuştur. Nitekim bu husus Avrupa Para Birliği kurulmadan önce birçok ünlü iktisatçı tarafından dile getirilmiştir. Bu bağlamda büyüme modelinin hatalı bir şekilde tasarımının yanı sıra büyüme modeli sonrası para alanına dâhil edilen ülkelerin yapısal zayıflıkları da krizin ortaya çıkışında önemli rol oynamıştır.

$A B$ ve Euro Bölgesinde yapısal zayıflıkları olan ülkeler genel olarak güney ülkeleridir. Bu ülkeler, PIIGS ülkeleri olarak isimlendirilmiştir. Tek para uygulaması ile Euro Bölgesinde faiz oranlarının parasal birlik kurulmadan önceki Alman Markının faiz oranlarına yaklaşmaya başlaması, bu ülkelerin borçlanma maliyetlerini düşürmüştür. Bu düşüş ise PIIGS ülkelerindeki finansman ve tasarruf açığının Euro piyasalarından borçlanılarak kapatılmasını teşvik etmiştir.

$\mathrm{Bu}$ çerçevede artan kamu borçları ile beraber bütçe açığı sorunu ortaya çıkmıştır. PIIGS ülkelerinde mali disiplin sorunlarının olması kamu borçlanmasının yönetimini zorlaştırmıştır. Bu ülkeler aşırı borçlanmaya gitmişler ve bu borçları yine tekrar borçlanarak finanse etmeye çalışmışlardır. Bir başka yönden Euro Bölgesinde bankacılık sektörü ve finans sektörü arasındaki etkileşimin yüksek olması da kamu borçlarını tetiklemiştir.

Tek para alanı uygulaması ile döviz kuru riskinin minimize edilmesi ve işlem maliyetlerinin azalması Euro Bölgesinin kuzeyinden güneyine dış ticareti geliştirmiştir. Bu bağlamda PIIGS ülkeleri ithalata dayalı büyüme gerçekleştirmişler ve cari açık vermişlerdir. Kuzey ülkeleri ise güneye yaptıkları ihracatın artması ile cari fazla vermeye başlamışlardır.

Euro Bölgesi Güney ülkelerinin cari açık, kuzey ülkelerinin cari fazla vermelerinin temelinde güney ülkelerindeki rekabet gücü sorunu yatmaktadır. Güney ülkeleri yükselen zenginlik artısı sonrası reel ücretleri 2002 yılı seviyelerinde dengeleyememişler ve ortaya çıkan ücret artışları verimlilik artışından daha yüksek seviyelerde gerçekleşmiştir.

Bir diğer yönden bu ülkeler enflasyonu Euro Bölgesi ortalamasında baskılayamamışlardır. Kuzey ülkeleri ise reel ücretleri 2002 yılı seviyelerinde sabitlemişler ve enflasyonu baskı altında tutmuşlardır. Nihayetinde güney ülkelerinde reel efektif kur değerlenirken kuzey ülkelerinde değer kaybetmiştir. Bu durum güneyin rekabet gücünün aşınmasına, kuzeyin rekabet gücünün artmasına neden olmuştur. Sonuçta güney ülkeleri cari açık, kuzey ülkeleri cari fazla vermişlerdir.

Bir diğer yönden, $\mathrm{AB}$ genelinde tam siyasi ve ekonomik bütünleşme sürecini ilerletecek bir takım mekanizmaların eksikliği ve var olan mekanizmaların etkin çalışmaması da kriz sürecinde önemli rol oynamıştır. 
En başından tasarımı sorunlu ve yapısal zayıflıkları olan ülkelere sahip olan Euro Bölgesi 2009 yılına kadar kısmen başarılı olarak devam etmiştir. (Ergin, 2013) 2002-2008 arası dönemde PIIGS ülkeleri kayda değer ekonomik büyüme sağlamışlardır. Ancak parasal birliğin tasarımındaki hatalar ve yapısal zayıflıkların Euro Bölgesinde krizler çıkarabileceği parasal birliğin kurulmasından çok önceleri tahmin edile gelmiştir. Hatta ikinci bölümde vurgulandığı üzere $\mathrm{AB}^{\prime}$ nin Euro'ya olan sadakatinin Euro Bölgesinde ortaya çıkacak ilk büyük problemle sınanacağ 1 iddia edilmiştir (Kibriçioğlu, 2011).

Bu bağlamda Euro Bölgesinde ilk problem A.B.D' de konut kredileri piyasasında ortaya çıkan eşik altı krizinin, Lehman Brothers' in iflası ile küreselleşmesi ile ortaya çıkmıştır. Küresel finansal kriz tüm küresel sistemde finans sektörünün ardından reel sektöre bulaşarak, ekonomileri küçültmüştür. Ayrıca krizin, küresel finansal sistemin geleceğinin sorgulanmaya başlamasına yol açması küresel sistemin riskini artırmıştır.

Küresel kriz bağlamında risk artışından en fazla olumsuz etkilenen ekonomik sistemler $A B$ ve Euro Bölgesi olmuştur. Çünkü AB-Euro Bölgesi ve A.B.D finansal ve ekonomik sistemleri arasındaki sistemik bağlılık dış ticaret ve finans kanalı çerçevesinde oldukça yüksektir.

Bir diğer yönden Küresel Finansal Krizin ortaya çıkışında türev finansal araçlar önemli rol oynamıştır A.B.D' de ihraç edilen türev araçların vade dönüşümlerinin ve fonlanmasının başta İngiltere olmak üzere $A B$ içindeki finans kuruluşları tarafından gölge bankacılık faaliyetleri kapsamında yapılması ve bu araçların $A B^{\prime}$ nin büyük finans kuruluşları tarafından spekülatif amaçlı satın alınması küresel krizin $\mathrm{AB}^{\prime}$ deki yayılımı ve derinleşmesinde önemli rol oynamıştır. Artan risk sonrası Euro Bölgesinde borçlanma maliyetlerinin artmasına neden olmuştur. Bu artış en fazla 10 yıllık devlet tahvil faizlerinde gerçekleşmiştir.

Euro Bölgesinde makroekonomik kırılganlığı en yüksek olan ülke Yunanistan'dır. Bu nedenle Yunanistan'ın tahvil faizlerindeki artış diğer ülkelere oranla daha fazla gerçekleşmiştir. Borçlarını borçla finanse eden Yunanistan'ın tahvil faizlerinin artması bu ülkede borçlanma dinamiğinin yapısını bozmuştur. Yunanistan borçlanma dinamiğinin bozulması sonucu borçlarını çevirememeye başlamıştır.

Avrupa Borç krizinin ortaya çıkmasında fitili ateşleyen gelişmeler 2009 yılı sonbaharında gerçekleşmiştir. 2009 yılı Ekim ayında Yunanistan'da göreve gelen yeni hükümet kendinden önceki hükümet dönemindeki makroekonomik verileri revize etmiştir. Bu revize işlemi ise Yunanistan'ın kamu borçlarının mevcut seviyesinden daha yüksek seviyelerde olduğunu ortaya çıkarmıştır. Devamında Yunanistan borçlarını ödeyemeyeceğini ilan etmiştir.

Yunanistan devlet tahvillerinin büyük çoğunluğunun Almanya ve Fransa'daki bankaların bilançolarında bulunması Euro Bölgesi ve $A B^{\prime}$ de bankacıllk sektörü ve finans sektörünün sistemik riskinin artmaya başlamasına neden olmuştur. Bu durum ise bankaların likidite sıkıntısı çekmesine yol açmıştır.

Yunanistan'ın kamu borç krizine sürüklenmesi, Yunanistan' da olanların neden diğer yapısal zayıflıkları olan ülkelerde olmasın düşüncesinin yatırımcılar nezdinde fiyatlanmasına neden olmuştur. Bu nedenle Euro Bölgesinde devlet tahvil faizleri Yunanistan tahvil faizlerine yakınsamaya başlamıştır. Nihayetinde Yunanistan'la benzer makroekonomik görünümüne sahip Portekiz'de borçlarını çeviremeyerek kamu borç krizine sürüklenmiştir. Devamında Portekiz'in ardından İrlanda, İspanya ve İtalya'da krize sürüklenmiştir. Bu bağlamda borç krizi Euro Bölgesinde ülkelerin kırılganlıklarına göre seçici etki yaparak yayılmıştır (TCMB, 2012). 
$\mathrm{AB}$ ekonomi yönetiminin ve birliğin lokomotif ülkelerinin krizin çözümünde başta isteksiz davranmaları, $\mathrm{AB}$ ve Euro Bölgesi piyasalarında riski daha da artmıştır. Artan risk sonrası krizin kronikleşmesi ve derinleşmesi nedeniyle AB'nin Yunanistan ve Portekiz için devasa kurtarma paketlerini onaylaması bu seferde $A B$ ve Euro Bölgesinin geleceğinin ciddi ölçüde tehdit altında olduğu algısı çerçevesinde riski artırmıştır. Bir diğer yönden bu süreçte kredi derecelendirme kuruluşlarının yaptıkları not indirimleri krizin bulaşıcılığı ve yayılma hızını artırarak krizin derinleştirmiştir.

\section{KAYNAKÇA}

ABGS. (2011). Ekonomik ve Mali Politikalar Başkanlı̆̆ı, Avrupa Birliği"nde Küresel Finansal Krize Karşı Alınan Önlemler ve Birliğin Rekabet Gücünün Arttırlmasına Yönelik Girişimler: Euro Rekabet Paktı",: Ankara, (http://www.abgs.gov.tr/files/EMPB/euro plus pact.pdf, (Erişim Tarihi: 10. 10. 2013).

Akçay, B. (2013). Avrupayı Saran Kriz (Avro Bölgesi), Seçkin Yayıncılık, İstanbul.

Barosso,(2011).Taking Stock Of The Euro Plus Pact,

http://ec.europa.eu/europe2020/pdf/euro_plus_pact_presentation_december_2011_en.pdf, (Erişim Tarihi: 04. 12. 2013).

Bordo, M. and Eichengreen, B. (1999). Is Our Current International Economic Environment Unusually Crisis Prone? in David Gruen and Luke Gower (eds)., Capital Flows and the International Financial System, Sydney: Reserve Bank of Australia.

Chamon, M. (2007). Can debt crises be self-fulfilling?, Journal of Development Economics, 82, 234244.

Constâncio, V. (2012). Contagion And The European Debt Crisis Financial Stability Review $\bullet$ No. $16 \bullet$ April.

Corsetti, G., Pericoli, M. and Sbracia, M. (2011). "Correlation Analysis Of Financial Contagion", http://www.econ.yale.edu/growth_pdf/cdp822.pdf (Erişim Tarihi: 12. 10. 2013).

Dağdelen,(2011). (http://www.businessweek.com/news/2010-05-14/euro-breakup-talk increasesas-germany-loses-proxy-update1-.html) (Erişim Tarihi: 12. 10. 2013).

Değerli, A. ve Keleş, G. (13/ 16 Eylul 2011). Kamu Borç Stoku Sürdürülebilirliği ve Euro Bölgesi Borç Krizi, Türkiye Cumhuriyeti Merkez Bankası Ekonomi Notları.

Ergin, N. E. (2013). Hasta Adam Avrupa: Avro Krizi, Hesap Uzmanları Derneği Yayınları, İstanbul.

Grafton, Q. (2011). "Sovereign Debt Crises, ; Real Economy and ; Euro Zone Crisis", (Çevrimiçi) http://bree.gov.au/ documents/ publications/ REQ_Review_Sovereign_ Debt_Crises_ Dec2011.doc, 1-5, adresinden 17 Ocak 2012' de alınmıştır.

Grauwe, P. (2010). "Crisis in the Eurozone and How to Deal with it?", CEPS Policy Brief, No.204.

Hautcoeur, P.C. (2011). Chaque Grande Crise Est Différente. Economie et Statistique, 438-440, 1-4. 
Hilsenrath, J. "Q\&A: Carmen Re\&nhart on Greece, U.S. Debt and Other'Scary Scenar\&os'”, -e Wall Street Journal, http://blogs.wsj.com/economics/2010 /02/05/qa-carmen-reinhart-ongreece-us-debtand-other-scary-scenarios/, adresinden 29 Ocak 2011'den alınmıştır.

IMF, (2012). Greece: Fourth Review Under the Extended Arrangement Under the Extended Fund Facility, and Request for Waivers of Applicability and Modification of Performance Criterion-Staff Report; Staff Statement; Press Release; and Statement by the Executive Director for Greece, Country Report, 12/57.

Kaya, N., Barlas, Y. ve Kalafatcılar, K. (2011). Euro Bölgesi Çevre Ülke Ekonomilerinin Kırılganlıkları ve Bankacılık Sektörlerinin Karşıllklı Duyarlılıkları, Türkiye Cumhuriyeti Merkez Bankası Ekonomi Notları.

Kılıç, C. ve Bayar, Y. (2012). Euro Bölgesi Borç Krizinin Türkiye Ekonomisi' ne Olası Yansımaları Üzerine Bir Değerlendirme, Ekonomi ve Yönetim Araştırmaları Dergisi, 1 (2).

Kibritçioğlu, A. (2011). Current Sovereign Dept Crisis in Eurozone Countries. Munich Mersonal RePEc Archive, MPRA Paper No.33528.

Küçüksaraç, D., Özlü, P., Ünalmış D. (2012). Küresel Kriz, Avrupa Borç Krizi ve Gelişmekte Olan Piyasalarda Bulaşıcılık Etkisi, Türkiye Cumhuriyeti Merkez Bankası Ekonomi Notları.

Lapavitsas, C. Kaltenbrunner, A., Lambrinidis, G., Lındo, D., Meadway, J., Mİchell, J., Paİnceira, J. P., Prres, E., Powell, J., Stenfors A. and Teles N. (2010). Eurozone Between Austerity and Default, Research on Money and Finance (RMF)., RMF Occas\&onal Report, 1-69.

Massa, I., K., J. and Kennan, J. (2011). "The Euro Zone Crisis: Risks for Developing Countries", Background Note, İngiltere: Overseas Development Institute.

Mink, M., and De Haan, J. (2013). Contagion during the Greek sovereign debt crisis. Journal of International Money and Finance, 34, 102-113.

Mishkin, F. S. (1995). "Symposium on the Monetary Transmission Mechanism". The Journal of Economic Perspectives, 9 (4), 3-10

Nemeth, F. European Debt Crisis - Origin, Consequences And Potential Solutions, http://www.derivat.sk/files/fsn\%202012/Nemeth.pdf (Erişim Tarihi: 16. 11. 2013).

Rangaua,U., L. and Burietz, A. (2013). One Crisis, Two Crises...The Subprime Crisis And The European Sovereign Debt Problems, Economic Modelling, 35, 35-44.

Reinhart, C. M. (2009). Economic and Fiscal Consequences of Financial Crises, Munich Personal Repec Archive (MPRA)., MPRA Paper No. 13025, 1-11, (Çevrimiçi).

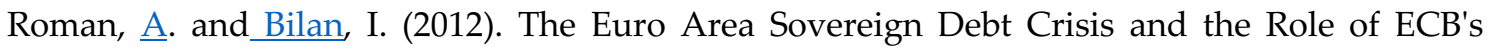
Monetary Policy, ProcediaEconomics and Finance, 3, 763-768.

Sezgin, Z. (2012). Küresel Krizin İkinci Perdesi: 2011 Avrupa Borç Krizi, İşletme Araştırmaları Dergisi 4 (2), 141-150. 
Şanlığlu, Ö. ve Bilginoğlu, M. A. (2010). Euro Bölgesi'nde Yaşanan Mali Sorunlar Ve Maliye Politikalarında Uyum Arayışları, Erciyes Üniversitesi İktisadi ve İdari Bilimler Fakültesi Dergisi, 35, 149-173.

Topçu, M. K., Gürson, P., Ülker H. İ. and Erkan, T. E. (2013). AB Borç Krizi ve Aktarmm Mekanizmaları ile Yayılımı: Türkiye'ye Muhtemel Etkileri, International Conference On Eurasian Economie.

Usak Raporları,(2011), Krizdeki Birlik Euro Bölgesi'nin Borç Sarmalı ve AB'nin Geleceği, Usak Raporları Rapor No. 11-01, Mart 2011 No: 11-01mart 2011

İnternet Kaynaklar1:

(http://sdw.ecb.europa.eu/browseSelection.do?DATASET=0\&DATASET=1\&sfl1=4\&FREQ=M\&s $\mathrm{fl} 2=4 \&$ node=SEARCHRESULTS\&q=long+term+interest+rate, Erişim Tarihi, 17.01.2014).

TCMB,2012, http://www.tcmb.gov.tr/yeni/duyuru/2012/Baskan_SDE.php, (Erişim Tarihi: 05. 05. 2013).

http://www.bis.org/index.htm (Erişim Tarihi: 12. 10. 2013).

http://thomsonreuters.com/ 